Wright State University

CORE Scholar

4-1993

\title{
Victimization in Library School Closing Rhetoric: A Response to a Library Quarterly Symposium
}

\author{
Stephen Paul Foster \\ Wright State University, stephen.foster@wright.edu
}

Follow this and additional works at: https://corescholar.libraries.wright.edu/ul_pub

Part of the Library and Information Science Commons

\section{Repository Citation \\ Foster, S. P. (1993). Victimization in Library School Closing Rhetoric: A Response to a Library Quarterly Symposium. The Library Quarterly, 63 (2), 199-205. \\ https://corescholar.libraries.wright.edu/ul_pub/133}

This Response or Comment is brought to you for free and open access by the University Libraries at CORE Scholar. It has been accepted for inclusion in University Libraries' Staff Publications by an authorized administrator of CORE Scholar. For more information, please contact library-corescholar@wright.edu. 

VICTIMIZATION IN LIBRARY SCHOOL CLOSING RHETORIC:
A RESPONSE TO A LIBRARY QUARTERLY SYMPOSIUM

\author{
Stephen P. Foster ${ }^{2}$
}

Librarianship continues to witness the closing of its professional schools, including the recent elimination of two of its oldest and most prestigious graduate programs. The closures raise important questions about the profession and suggest that critical scrutiny is needed, not only of the processes of change that bring about the closings but also of librarianship's own rhetoric of response to the closings. This article is a critique of the July 1991 Library Quarterly symposium on graduate library school program elimination. It focuses on the rhetoric of three of the symposium articles.

From 1978 to 1991 the curtain has dropped on fourteen graduate library programs in both public and private universities [1, pp. 259-60], not including Brigham Young University's School of Library Science, which has recently announced its closing [2]. Library schools have closed during a period when the technology governing the production and dissemination of intellectual property (the primary material of library services) has been radically transformed and at a time when public financial support for education and educational-support institutions, like libraries, has eroded. The sweeping technological changes affecting libraries, combined with predictions of long-term budgetary constraints, place enormous pressure on the profession of librarianship. Unfortunately, the profession is very much on the defensive, as perhaps most dramatically illustrated by the widespread elimination by universities of their professional schools. In recent years, two of the oldest and most prestigious programs - those at Columbia University and the University of Chicago-have been closed. The Graduate Library School at the University of Chicago was the first and for many years the only program that granted Ph.D.'s in librarianship [3, p. 69].

1. This article is a revised version of a paper delivered to the Library and Information Sciences Section of the Michigan Academy of Sciences, Arts, and Letters at the March 1992 annual meeting.

2. Central Michigan University Libraries, Mount Pleasant, Michigan 48859.

[Library Quarterly, vol. 63, no. 2, pp. 199-205]

(C) 1993 by The University of Chicago. All rights reserved.

0024-2519/93/6302-0004\$01.00 
The phenomenon of library school closings was the topic of a Library Quarterly "symposium" titled "Perspectives on the Elimination of Graduate Programs in Library and Information Studies" published in its July 1991 issue [1]. The symposium includes six articles written by university library and information studies faculty and has what appears to be two general aims: (1) to explain why library education is held, relatively speaking, in low esteem and hence why graduate programs in librarianship have been so routinely and rudely cast aside, and (2) to exhort fellow library educators and librarians to prosecute some course of action that will ultimately protect and improve existing programs and also elevate the status of librarianship in the university community.

This article is a response to the symposium, though only to the first three of the six pieces. A variety of interesting perspectives and concerns emerge from the symposium, such as the impact of librarianship on distance education and the importance of policy participation by library and information science faculty. However, the first three articles, by Marion Paris, Herbert S. White, and Margaret Stieg, with their intense preoccupation with librarianship's perceived lack of status as a profession, feature the library school closing phenomenon as a kind of public relations problem. In my view, this is a somewhat constricted perspective. From these articles, with the familiar and perhaps overwrought theme of librarianship as a second-class profession, comes the pat, perhaps self-serving, and self-fulfilling conclusion that the demise of library schools is the effect of a long-standing misunderstanding and undervaluing of the profession. The rhetoric of the articles has the effect of placing the discussion of the issue almost entirely in a context of victimization with a focus on rather subjective and problematic questions of how librarians and librarianship should be regarded.

This response claims no insights on why so many library school closings have taken and continue to take place. The subject is complex and would, I believe, be particularly well suited for multidisciplinary study. What the response does attempt is to offer a critical perspective on a common theme in professional library literature (the prominent theme of these three articles): professional inferiority-a theme manifest in the myriad expressions of hyperbolic self-examination, the effusive but specious self-affirmations, and the frequent appeals to victimization. It also poses a question: Does the rhetoric of victimization run the risk of accusing the victim?

Marion Paris wrote the short introductory article for the symposium under the title "Library School Closings: The Need for Action." Paris quotes from the "Resolution on Closing of Schools of Library and Information Science" passed by the Council of the American Library Association in 1990: "The assumption [is] that no matter how high the quality 
of the library-information school, librarianship as a discipline lacks merit in research universities in the U.S. with the implied assumption that librarianship is not a profession of standing" [1, p. 261].

This reads like a proclamation of defeat. It promises nothing but hard times for the profession and conveys an almost desperate sense of professional inferiority. But more interesting, and indirectly related to the issue of professional inferiority, is Paris's account of her research. She states: "A doctoral dissertation, which I completed in 1986, described four of the [library school] closings in detail. Its principal finding was that, whereas financial exigency had been named by university officials as having motivated the closings, other factors were involved as well" $[1$, p. 260]. Paris then briefly elaborates on those other factors. Consider, though, the implications of the choice of the dissertation topic. Librarianship's place in the research community is suspect, the author notes, because the discipline is reputed to lack merit. As she adds, officials at Emory University and the University of Chicago opined that research universities have no place for library schools [1, p. 261]. If this is the case, then it would seem that the very existence of library schools in research universities would depend heavily on the development of a unique and powerful research agenda that would render it a difficult, indeed irresponsible, decision to close them. However, taking note of the mention of this dissertation topic, one might well be tempted to ask: If the serious research supported by the graduate programs in librarianship is not perceived to be on par with that in other programs, then should not the profession of librarianship (for purposes, initially, of survival) hold itself to a higher standard, and should not its young scholars emerging from its best graduate schools be expected to display their research virtuosity and a fresh capacity to advance the discipline with innovative dissertations? Instead, we have the rather odd and anomalous spectacle of graduate library programs turning out dissertations on the dissolution of graduate library programs and conveying the impression of a profession that is moribund, backward looking, and defensive.

Consider what a dissertation is supposed to be (in some idealized sense), what a dissertation author is actually attempting to do (as far as moving through a professional rite of passage), and what the dissertation text actually tells us about the discipline from which it is emerging. Then try to imagine how a clever, au courant deconstructionist might look at this particular situation. Deconstructionists focus on texts as ambiguous, "unstable" vehicles of meaning that, critically read and interpreted, reveal and ultimately undermine, to use the rebarbative argot, "repressive structures of binary opposition" [4, p. xi]. How might such an undermining occur in this case? Here we have the author of a disser- 
tation writing about the demise of professional education programs of the same kind in which the author is attempting to advance, with the purpose of making a contribution to the research literature in that profession and making a sociological assessment about the demise of that profession. These so-called binary oppositions between author and subject and between the author's purposes are offered merely to suggest that graduate library education, at least as instanced by this dissertation, reveals a kind of implosion process whereby the actual destruction of the profession's educational programs becomes the subject matter of the profession's remaining programs.

Herbert S. White's article, "Politics, the World We Live In," provides an explanation for the wave of library school closings that I would characterize as Hobbesian in outlook. Library education programs, he surmises, have simply been too weak, too small, and too lacking in prestige-easy prey for bottom-line-preoccupied university administrators increasingly pressured to hack up and redistribute an ever-shrinking resource pie. It is a depressing account replete with the themes of victimization and alienation. Consider the following: "Evaluating and closing academic programs is a ceremonial exercise aimed at creating the appearance of a new style of cost-effective management, even when the structure of the university makes that difficult if not impossible to achieve. And so victims must be found. Sacrificing the small, the weak, and the cheap results in no significant savings, which can only come from eliminating large programs and major divisions. Yet the large are also too powerful and too deeply entrenched to be touched" [1, p. 263].

The analysis does not aim for subtlety, and the verdict is obvious: only the strong survive. But there is even more bad news: "A more serious threat to library education comes from our academic colleagues, who do not know us, do not understand us, and do not appreciate us" [1, p. 264]. Not only are library education programs menaced from above by hostile university bureaucrats who are impressed only by size and numbers, but they are also undermined from within by the indifference of colleagues and the concomitant institutional isolation that it produces.

What then is to be done? Unfortunately, White's exhortations are as vague as his analysis is bleak. He says: "If we do not recognize the current and future political realities of higher education, our recent history will continue to repeat itself with even more disturbing, and more far-reaching, consequences" [1, p. 266]. But given his explanation of library school closings as exercises in pure political power, it is difficult to grasp what difference mere recognition of current political realities could make. Acute recognition is perfectly consistent with weakness. I think it is unlikely that the collegial indifference that White complains of will be drastically altered in the near future, or that graduate pro- 
grams in librarianship will "muscle up" sufficiently to impress university administrators. Moreover, White's suggestion that collegial indifference is a significant factor in making library programs so vulnerable is actually off the mark, since universities have become so widely and pervasively fragmented and compartmentalized, even within departments, that many or most of the disciplines exist in a state of mutual isolation and indifference [5]. C. P. Snow's much discussed Two Cultures and the Scientific Revolution, written over thirty years ago, could very likely be revised to address a multiplicity of mutually antagonistic cultures within the present-day university [6].

White exhorts library educators to "reexamine, revalidate, and perhaps republicize our roots" [1, p. 266]. This is vague and puzzling as well. What, I might ask, exactly would we be doing by "revalidating our roots"? Who is the republicizing for? What power realignments result from reexamination? How would any of these three activities alter the political realities that continue to threaten graduate library education?

The thrust of White's article is to blame the dissolution of library programs on university politics while suggesting that the intrinsic value of librarianship actually makes them worth preserving. White's actual analysis, however, fails to point beyond university politics, and the gloomy picture he paints of how it works and of librarianship's vulnerability would only seem to spell inevitable decline. In fact, his entire discussion winds up on the horns of a dilemma. If, on the one hand, the key to the survival of library education somehow lies in playing the power games, then librarianship, it would seem, is doomed because it is not likely, given recent history, that it can muster the power resources to win. But if, on the other hand, librarianship has intrinsic value and a claim to respect and recognition, then there are issues to be considered beyond politics.

Margaret Stieg follows closely the Hobbesian path set by White. Stieg titles her article "The Closing of the Library Schools: Darwinism at the University." The title itself raises questions. Why "Darwinism" rather than the more obvious and appropriate "social Darwinism"? Darwinism is a biological theory, presumably value free, which explains how the survival of living species is related to the traits they acquire, while social Darwinism is an ethical theory that argues that the survival of the strong is right and appropriate. If indeed, the closing of library schools is simply Darwinian, then it would seem there is no basis for remonstration, merely detached observation. But this is not what the article is about.

Stieg, like White, is not loath to note that library education programs have been so expendable because they lack the requisite accoutrements of power and prestige. "Nor does a library school enhance a university's elite image. Inevitably, it has the coloration of its profession, and librari- 
ans have few high-status characteristics. In a society where money talks, librarians are poor compared to lawyers, doctors, and business executives" [1, p. 270]. Stieg, however, takes the analysis a step beyond White's. The problem is not simply that librarianship lacks power; rather, it lacks an established theoretical core sufficient to give it full professional identity and ultimately respectability. Librarianship's history, she suggests, is one of a groping to create itself, particularly in its theoretical alignments.

"Library education has valiantly tried to redesign itself to better suit the priorities of universities. At various times it has tried to become a science, to become theoretical, and to recruit more men and scientists. Now it is trying to accomplish all of these at one time by becoming information science. But its efforts at adaptation have had only limited success. The profession it serves remains, and therefore it remains, stubbornly humanistic, service oriented, and female in composition" [1, p. 271].

Stieg thus indirectly suggests that the best course of action for librarianship is to identify itself as a humanistic rather than a scientific profession. The scientific- versus humanistic-based concept of the profession has an interesting history, most ably presented in the volume edited by Fritz Machlup and Una Mansfield, The Study of Information [7]. Certainly, librarianship is a service-oriented profession. Whether it remains, or ever was, humanistic is a matter of debate.

Stieg, however, remains optimistic about the future of library education. "Signs of dissatisfaction with the priorities of research universities are beginning to appear. . . . If the harsh materialism practiced by universities can be influenced by the desire for a kinder, gentler society now beginning to be expressed, those essentially humanistic fields like librarianship will be less out of step" [1, pp. 271-72, italics added]. Specific "humanistic fields" besides librarianship are never mentioned. Stieg also provides no examples or evidence for those "signs of dissatisfaction" with current priorities at research universities, a claim that is belied by an announcement in a recent issue of American Libraries of another library school closing: this one at Northern Illinois University [8]. The recent appointment of a nonlibrarian as dean of the University of Michigan's School of Library and Information Studies would be another event that makes her optimism misplaced.

The rhetoric of the articles considered in this response tends to be cast in the framework of institutional victimization: amoral forces at work within the university moved only by considerations of power, prestige, and money. However, victimization as an explanation has certain risks. It can appear to be self-serving and rationalizing because the victim disclaims responsibility. The disclaimer may in fact be interpreted 
as rationalization. While it is true that the evil that befalls a victim is not his or her responsibility, the person claiming victim status calls attention to his or her vulnerability and weakness, which in turn become objects for criticism. Belying victim status for librarianship is the fact that the victimization claim is analogical. The cancellation of an academic program ultimately commits no crime: the failure of a program to survive may simply be the result of a concatenation of forces brought together by complex changes in society.

\section{REFERENCES}

1. "Perspectives on the Elimination of Graduate Programs in Library and Information Studies: A Symposium." Coordinated and introduced by Marion Paris. Library Quarterly 61 (July 1991): 259-92.

2. Marchant, Maurice. "The Closing of the Library School at Brigham Young University." American Libraries 23 (January 1992): 32-36.

3. Houser, L., and Schrader, Alvin M. The Search for a Profession: Library Science Education in the U.S. and Canada. Metuchen, N.J.: Scarecrow, 1969.

4. Game, Ann. Undoing the Social: Towards a Deconstructive Sociology. Toronto: University of Toronto Press, 1991.

5. Wilshire, Bruce. The Moral Collapse of the University: Professionalism, Purity, and Alienation. Albany: State University of New York Press, 1990.

6. Snow, C. P. Two Cultures and the Scientific Revolution. New York: Cambridge University Press, 1959.

7. Machlup, Fritz, and Mansfield, Una, eds. The Study of Information: Interdisciplinary Messages. New York: Wiley, 1983.

8. "News Fronts." American Libraries 23 (May 1992): 351. 